Article

\title{
Corrosion Behavior of AZ91D Magnesium Alloy with a Calcium-Phosphate-Vanadium Composite Conversion Coating
}

\author{
Ruixue Sun *, Shuaikang Yang and Tao Lv \\ College of Materials Science and Engineering, Qingdao University of Science and Technology, \\ Qingdao 266042, China; ysk20151@163.com (S.Y.); 13285429013@163.com (T.L.) \\ * Correspondence: sunruixue@qust.edu.cn; Tel.: +86-532-8402-3446
}

Received: 22 April 2019; Accepted: 28 May 2019; Published: 11 June 2019

check for updates

\begin{abstract}
A novel self-healing calcium-phosphate-vanadium (Ca-P-V) composite coating on $\mathrm{Mg}$ alloy was successfully fabricated through a chemical conversion method. The effects of the vanadium concentration on the anticorrosion property of the substrate were also tested. The $\mathrm{Ca}-\mathrm{P}-\mathrm{V}$ coating with the main composition of $\mathrm{CaHPO}_{4}, \mathrm{Ca}_{3}\left(\mathrm{PO}_{4}\right)_{2}$, and $\mathrm{Mg}_{3}\left(\mathrm{PO}_{4}\right)_{2}$, with some hydroxides of $\mathrm{V}(\mathrm{V})$ dispersed into it has a similar morphology to the single vanadium coating. The corrosion behaviour of the $\mathrm{Ca}-\mathrm{P}-\mathrm{V}$ coating was studied through the electrochemical tests and the scratch immersion test in $3.5 \mathrm{wt} \% \mathrm{NaCl}$ solution. The results showed that the Ca-P-V coated samples not only exhibit good corrosion resistance property, but also show self-healing ability. The ions of $\mathrm{Ca}, \mathrm{P}$, and $\mathrm{V}$ released from the coating can migrate in the corrosion solution and form a new compound layer on the damaged zone.
\end{abstract}

Keywords: magnesium alloy; $\mathrm{Ca}-\mathrm{P}-\mathrm{V}$ composite coating; self-healing; corrosion resistance

\section{Introduction}

To enhance the anticorrosion property of Mg alloys, many types of protective measures have been applied, and one of the useful methods is to fabricate a chemical conversion coating on their surfaces [1-5]. Compared with other methods including anodizing [6,7], electroplating [8,9], plasma electrolytic oxidation $[10,11]$, radio frequency (RF) magnetron sputtering $[12,13]$, and laser surface melting [14], the chemical conversion method is interesting owing to its low cost, easy control, and efficiency [15]. Chromate conversion coating (CCC) is a traditional and representative coating on $\mathrm{Mg}$ alloys, but $\mathrm{Cr}(\mathrm{VI})$ has high toxicity and can cause environmental pollution and damage $[16,17]$. Therefore, it is necessary to develop eco-friendly protective coating systems with high corrosion resistance on magnesium alloys to replace CCCs.

Phosphate conversion coating on Mg alloys has been studied for many years, which is considered to be an alternative to CCC [18]. Some divalent cations such as $\mathrm{Ca}^{2+}, \mathrm{Zn}^{2+}$ and $\mathrm{Mn}^{2+}$ are usually added to the phosphating bath to further enhance the anticorrosion property of the phosphate conversion coating. In our previous study, we developed an environment-friendly calcium phosphate conversion coating on AZ91D alloy, and demonstrated an enhanced anticorrosion ability of the conversion coating [19]. Zeng et al. prepared Zn phosphate coating and Zn-Ca composite coating on AZ31 alloy [20]. The results showed that the $\mathrm{Zn}-\mathrm{Ca}$ coating was denser and exhibited better anticorrosion ability than the single $\mathrm{Zn}$ coating [20]. Chen et al. deposited a double-layered coating including $\mathrm{Mg}(\mathrm{OH})_{2}$ and $(\mathrm{Mg} / \mathrm{Mn})_{3}\left(\mathrm{PO}_{4}\right)_{2}$ on AZ91D alloy, which shows better corrosion resistance than CCC based on the result of the salt spray test [21]. Phosphate conversion coating has good corrosion resistance as proved by the researchers, but it does not show a "self-healing" ability. 
Vanadate conversion coating has gained much attention owing to a self-healing property similar to CCC. Hamdy et al. reported that a high concentration of vanadate solution $(50 \mathrm{~g} / \mathrm{L}) \mathrm{can}$ protect the substrate with a proven self-healing property [22]. They exhibited similar effects on the ZE41 alloy [23]. $\mathrm{Li}$ et al. have obtained the optimum operating conditions for a $\mathrm{V}$ coating on the substrate at $60{ }^{\circ} \mathrm{C}$, $0.6 \mathrm{M} \mathrm{NaVO}_{3}$ solution [24]. They proved the self-healing capabilities of vanadate conversion coating by electrochemical tests. To further enhance the anticorrosion ability of the vanadate based coating and reduce the concentration of vanadate, some researchers have designed self-healing composite coatings based on vanadium modified by other conversions. Jiang et al. prepared a $\mathrm{Ce}-\mathrm{V}$ composite layer on AZ31, which exhibits two layers with an amorphous structure and a significantly improved corrosion resistance than CCC on AZ31 alloy [25]. Liu et al. prepared a V-Zr composite conversion coating on $\mathrm{Al}$ alloy with a self-repairing ability [26].

Combining self-healing ability with improved corrosion resistance is a promising substitute coating for CCC on magnesium alloys. In this study, we report for the first time a novel calcium-phosphate-vanadium composite coating on AZ91D magnesium alloy by a facile chemical conversion method. Compared with the pure $\mathrm{Ca}-\mathrm{P}$ coating, the $\mathrm{Ca}-\mathrm{P}-\mathrm{V}$ composite coatings not only have high corrosion resistance but also have self-healing ability due to the addition of vanadium. The effect of metavanadate concentration on the anticorrosion property of the composite coating was studied. Scanning electron microscopy with energy dispersive spectroscopy (SEM-EDS) and X-ray photoelectron spectroscopy (XPS) were applied to study the morphology and composition of the composite coating. In particular, both electrochemical and scratch tests were used to prove the self-healing behaviour of the prepared composite coating.

\section{Materials and Methods}

\subsection{Materials and Surface Preparation}

As-cast AZ91D magnesium alloy (Hongqi Metal Materials, Yantai, China) with a chemical composition of $90.31 \mathrm{wt} \% \mathrm{Mg}, 8.77 \mathrm{wt} \% \mathrm{Al}, 0.74 \mathrm{wt} \% \mathrm{Zn}$ and $0.18 \mathrm{wt} \% \mathrm{Mn}$ as used as the substrate material. The alloy samples with a size of $12 \mathrm{~mm} \times 12 \mathrm{~mm} \times 12 \mathrm{~mm}$ were mechanically ground with $\mathrm{SiC}$ sandpaper up to 2000 grit, ultrasonically cleaned in acetone for $5 \mathrm{~min}$, rinsed with distilled water and then dried in air.

\subsection{Preparation of the Conversion Coating}

The pre-treated AZ91D substrates were directly immersed in a solution of ammonium dihydrogen phosphate $\left(\mathrm{NH}_{4} \mathrm{H}_{2} \mathrm{PO}_{4}, 0.2 \mathrm{M}\right)$, calcium nitrate $\left(\mathrm{Ca}\left(\mathrm{NO}_{3}\right)_{2}, 0.1 \mathrm{M}\right)$, sodium metavanadate $\left(\mathrm{NaVO}_{3}\right.$, $0.04,0.08$ and $0.12 \mathrm{M}$ ) with a $\mathrm{pH}$ of 3 at $40^{\circ} \mathrm{C}$ for $20 \mathrm{~min}$. Finally, the samples were removed from the solution, rinsed with distilled water, and dried in hot air.

\subsection{Surface Characterization}

The surface and cross-section morphologies of the as-prepared composite coating were observed by a field emission-scanning electron microscopy (FE-SEM, JSM-6700F, JEOL, Akishima, Japan) equipped with EDS (JSM-6700F, JEOL, Akishima, Japan). For cross-section observation, the coated sample was firstly embedded in resin under certain pressure and temperature, and then mechanically ground with $\mathrm{SiC}$ sandpaper up to 2000 grit. The chemical state of elements in the coating was analyzed by XPS using a XSAM800 (Kratos, Manchester, UK) instrument with Al K $\alpha$ radiation $(1486.6 \mathrm{eV})$.

\subsection{Electrochemical Measurements}

Electrochemical measurements were used to evaluate the corrosion resistance of the uncoated and $\mathrm{Ca}-\mathrm{P}-\mathrm{V}$ coated AZ91D samples in $3.5 \mathrm{wt} \% \mathrm{NaCl}$ solution at room temperature. The samples with an exposed surface area of $1.44 \mathrm{~cm}^{2}$ were moulded in epoxy resin for all the electrochemical tests. A classic three-electrode system consisting of a sample as a working electrode, a saturated calomel 
electrode (SCE) as the reference electrode, and a platinum foil as the counter electrode was used in this experiment. Polarization measurements were performed for samples previously immersed for $30 \mathrm{~min}$ at the open circuit potential (OCP) in $3.5 \mathrm{wt} \% \mathrm{NaCl}$ solution. The scan rate was $0.80 \mathrm{mV} / \mathrm{s}$ with a scan range of $\pm 250 \mathrm{mV}$ with reference to the OCP. Electrochemical impedance spectroscopy (EIS, CS380 in COM3, Wuhan Corrtest Instruments Corp., Ltd., Wuhan, China) measurements were carried out at OCP in the frequency range between $100 \mathrm{kHz}-10 \mathrm{mHz}$ using a $10 \mathrm{mV}$ amplitude perturbation. EIS data were analyzed by ZView software (version 3.0) to fit the experimental data and synthesize the equivalent circuit. All electrochemical tests were normally duplicated three times to confirm good reproducibility.

\subsection{Scratch Immersion Test}

The scratch immersion test was employed to testify the self-healing property of the Ca-P-V coated samples. A scratch was cut on the surface of the coated samples by using a scalpel, and they were immersed in $3.5 \mathrm{wt} \% \mathrm{NaCl}$ solution for 1, 2 and $3 \mathrm{~d}$. As a comparison, the same scratch immersion test was also conducted on the uncoated AZ91D substrate. The surface morphologies and elements composition of the scratch before and after immersion were observed by SEM-EDS analysis.

\section{Results and Discussion}

\subsection{Effect of $\mathrm{NaVO}_{3}$ Concentration on the Corrosion Resistance of the $\mathrm{Ca}-\mathrm{P}-\mathrm{V}$ Composite Coating}

To obtain the optimum concentration of $\mathrm{NaVO}_{3}$, EIS measurements of the specimens were used in this study. Figure 1 presents the Nyquist plots for specimens coated with or without the Ca-P-V composite coatings in $3.5 \mathrm{wt} \% \mathrm{NaCl}$ solution. Compared with the uncoated sample, all the coated samples show better anticorrosion property. By increasing the concentration of $\mathrm{NaVO}_{3}$, the capacitive loop diameter at high frequency also increases, which is related to high corrosion resistance. Moreover, the sample coated with $0.08 \mathrm{M} \mathrm{NaVO}_{3}$ shows the largest loop compared with other coated samples. According to the EIS results, the $0.08 \mathrm{M} \mathrm{NaVO}_{3}$ was selected as the optimum concentration to prepare the coated samples with $\mathrm{Ca}-\mathrm{P}-\mathrm{V}$ composite coatings.

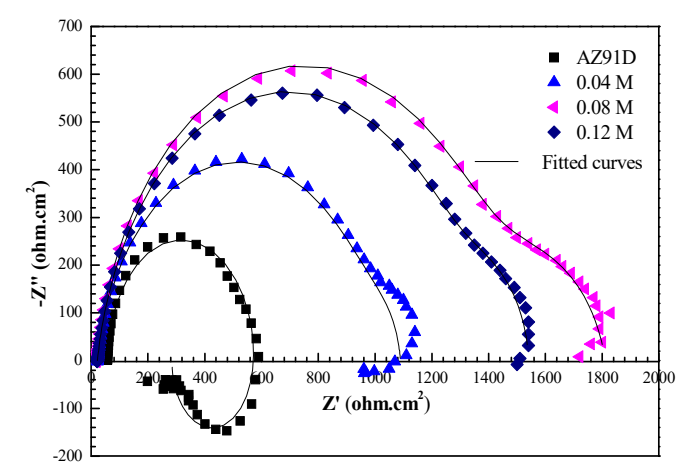

(a)

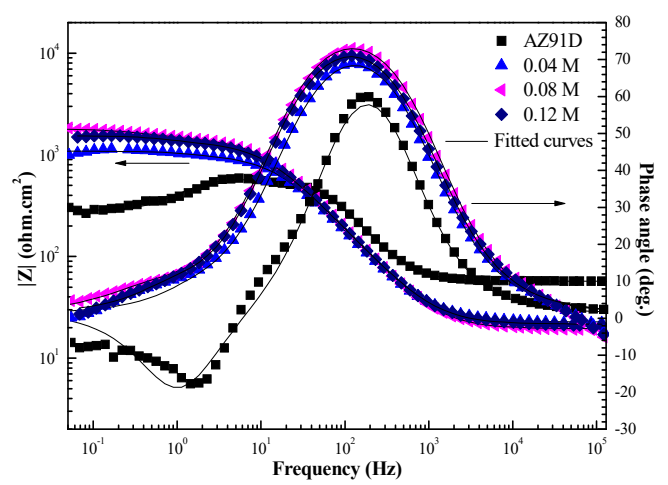

(b)

Figure 1. (a) Nyquist plots and (b) Bode plots for uncoated AZ91D substrate and Ca-P-V coated specimens at their open circuit with different $\mathrm{NaVO}_{3}$ concentrations in $3.5 \mathrm{wt} \% \mathrm{NaCl}$ solution (the samples are not soaked in solution before tests). Symbols are experimental data and solid lines are fitting data.

\subsection{Morphology and Composition of the $\mathrm{Ca}-\mathrm{P}-\mathrm{V}$ Composite Coating}

SEM images of surface morphologies of the single vanadium coating, $\mathrm{Ca}-\mathrm{P}$ as well as $\mathrm{Ca}-\mathrm{P}-\mathrm{V}$ composite coatings are presented in Figure 2. The Ca-P coating consists of a large number of plate-shaped particles (Figure 2b). While the Ca-P-V composite coating exhibits a grid-like structure with a large number of micro-cracks (Figure 2c), which is similar to the single vanadium coating 
(Figure 2a). Figure $2 \mathrm{~d}$ indicates that the composite coating has a thickness of about $\sim 1 \mu \mathrm{m}$. The element composition of the composite coating was analyzed through EDS as shown in Figure 2e and shows that the coating consists of $\mathrm{Mg}, \mathrm{Al}, \mathrm{Zn}, \mathrm{O}, \mathrm{Ca}, \mathrm{P}$ and $\mathrm{V}$ elements. Table 1 shows the contents of these elements obtained from EDS analysis. The EDS results of the pure vanadium as well as the Ca-P coating were also provided in Figure S1. The elements of $\mathrm{Mg}, \mathrm{Al}$, and $\mathrm{Zn}$ mainly come from the coating as well as the AZ91D substrate. The coexistence of $\mathrm{Ca}, \mathrm{P}$, and V suggests that the three elements of $\mathrm{Ca}$, $\mathrm{P}$, and $\mathrm{V}$ take part in the coating formation.

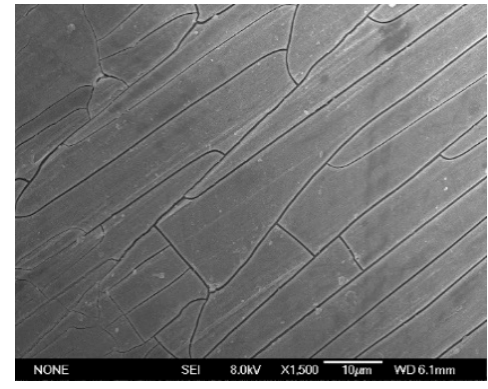

(a)

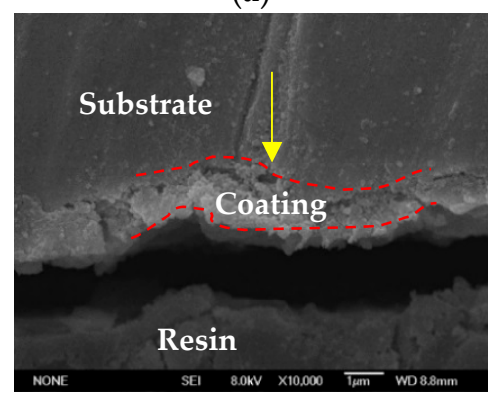

(d)

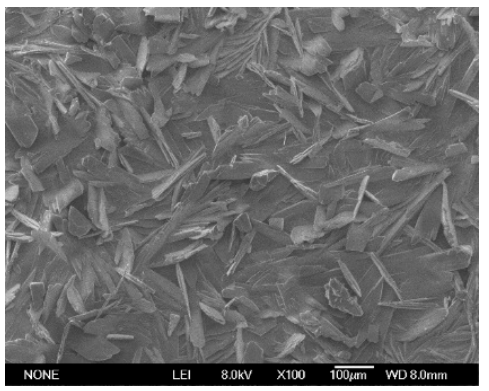

(b)

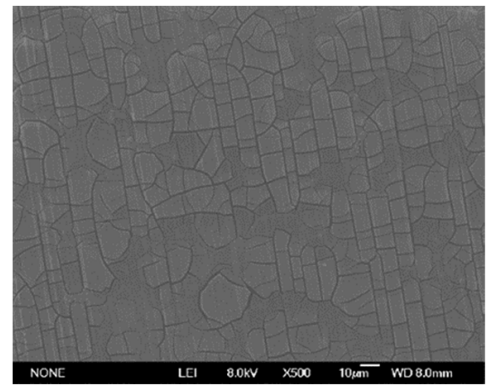

(c)

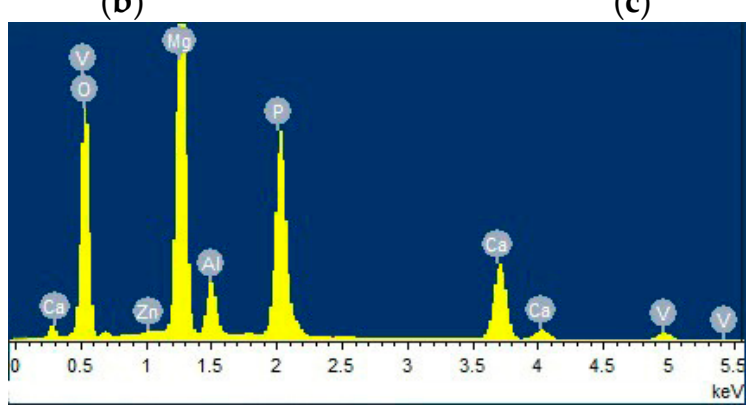

(e)

Figure 2. SEM morphologies of (a) single vanadium coating without $\mathrm{Ca}-\mathrm{P}$; (b) $\mathrm{Ca}-\mathrm{P}$ coating without $\mathrm{V}$ and (c) Ca-P-V composite coating; (d) cross-sectional micrograph of Ca-P-V composite coating; (e) EDS analysis of Ca-P-V composite coating.

Table 1. Contents of various elements obtained from EDS analysis of the Ca-P-V composite coating.

\begin{tabular}{cccccccc}
\hline Elements & $\mathbf{M g}$ & $\mathbf{A l}$ & $\mathbf{Z n}$ & $\mathbf{O}$ & $\mathbf{C a}$ & $\mathbf{P}$ & $\mathbf{V}$ \\
\hline at. \% & 19.2 & 2.7 & 0.1 & 63.0 & 4.3 & 10.1 & 0.6 \\
wt $\%$ & 22.6 & 3.5 & 0.2 & 48.7 & 8.4 & 15.1 & 1.6 \\
\hline
\end{tabular}

The XPS results of the composite $\mathrm{Ca}-\mathrm{P}-\mathrm{V}$ coating are shown in Figure 3. The XPS survey scanning spectrum indicates the coexistence of $\mathrm{Mg}, \mathrm{Ca}, \mathrm{O}, \mathrm{P}$ and $\mathrm{V}$ elements (Figure 3a), which is in agreement with the EDS result. Fitting the high-resolution XPS peaks for Ca $2 p, \mathrm{Mg} 2 p, \mathrm{P} 2 p$ and V $2 p$ are presented in Figure $3 b-f$, respectively. The peak of Ca $2 p$ is composed of $\mathrm{Ca} 2 p^{3 / 2}$ and Ca $2 p^{1 / 2}$ peaks. The binding energies of $\mathrm{Ca} 2 p^{3 / 2}$ peaks at 347.75 and $346.85 \mathrm{eV}$ can be attributed to $\mathrm{CaHPO}_{4} \cdot 2 \mathrm{H}_{2} \mathrm{O}$ and $\mathrm{Ca}_{3}\left(\mathrm{PO}_{4}\right)_{2}$, respectively $[27,28]$. The $\mathrm{Mg} 2 p$ in Figure $3 c$ displays three peaks, corresponding to $\mathrm{Mg}_{3}\left(\mathrm{PO}_{4}\right)_{2}, \mathrm{MgO}$ and $\mathrm{Mg}(\mathrm{OH})_{2}$, respectively $[21,27,28]$. As shown in Figure $3 \mathrm{~d}$, the P $2 p$ spectrum displays two peaks, corresponding to $\mathrm{PO}_{4}{ }^{3-}$ and $\mathrm{HPO}_{4}{ }^{2-}$ [28], which is in agreement with the result of Ca $2 p$. In Figure 3e, the binding energy of $\mathrm{V} 2 p^{3 / 2}$ is $517.5 \mathrm{eV}$ indicating $\mathrm{V}(\mathrm{V})$, but the $\mathrm{O} 1 \mathrm{~s}$ X-ray satellite peak has a serious impact on it [29-31]. Figure 3f shows the XPS spectrum of O 1s, which consists of two peaks. The binding energies at 530.56 and $531.60 \mathrm{eV}$ can be attributed to $\mathrm{V}-\mathrm{O}$ and $\mathrm{V}-\mathrm{OH}$, respectively [24,25]. Moreover, the peak at $531.60 \mathrm{eV}$ has much more intensity, proving that $\mathrm{V}-\mathrm{OH}$ (hydroxides) might be the main compound. In summary, the Ca-P-V composite coating mainly consists of $\mathrm{CaHPO}_{4} \cdot 2 \mathrm{H}_{2} \mathrm{O}_{\text {, }}$ $\mathrm{Ca}_{3}\left(\mathrm{PO}_{4}\right)_{2}, \mathrm{Mg}_{3}\left(\mathrm{PO}_{4}\right)_{2}$ and hydroxides of $\mathrm{V}(\mathrm{V})$. 


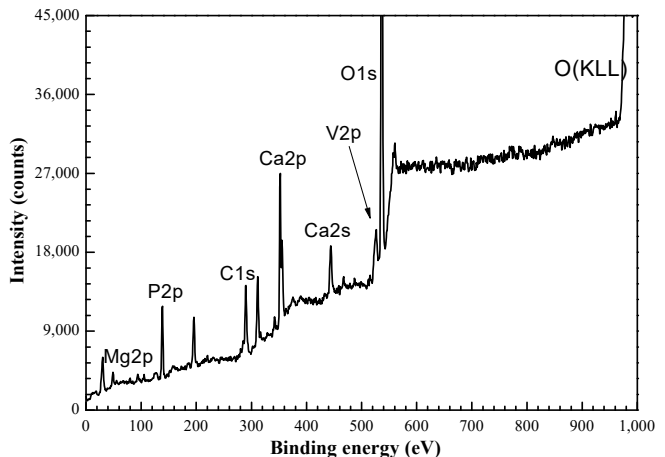

(a)

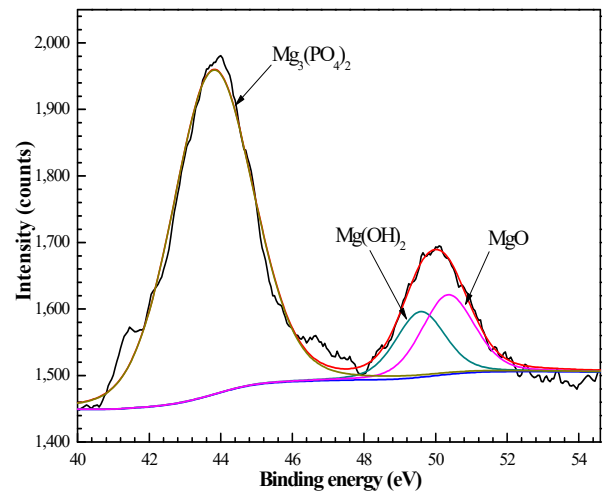

(c)

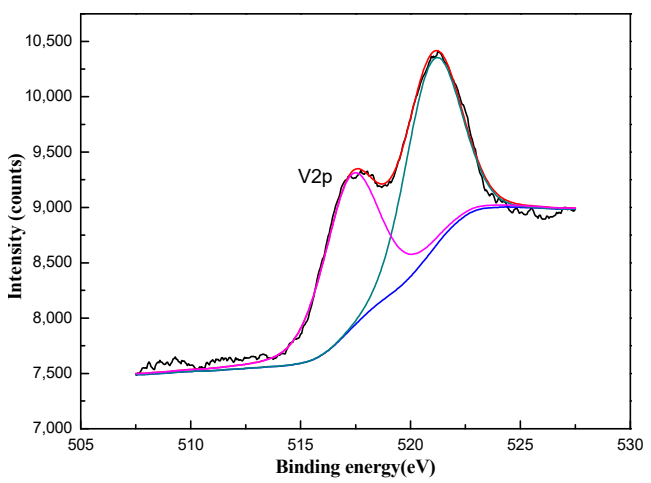

(e)

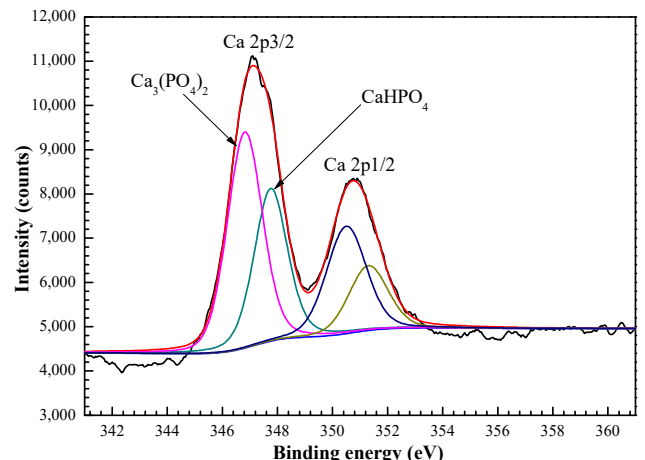

(b)

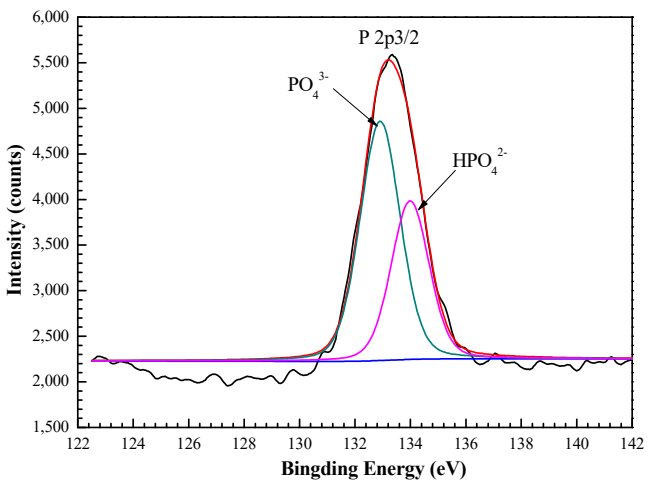

(d)

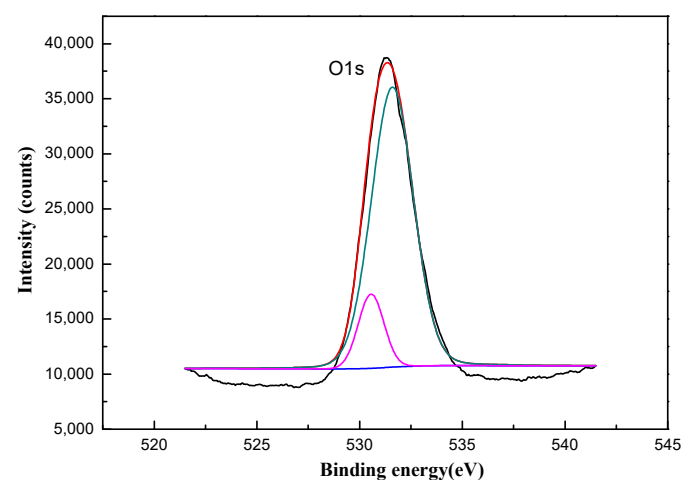

(f)

Figure 3. XPS patterns of the Ca-P-V composite coating: (a) The survey spectrum; (b) high-resolution spectrum of Ca $2 p$; (c) high-resolution spectrum of $\mathrm{Mg} 2 p$; (d) high-resolution spectrum of $\mathrm{P} 2 p$; (e) high-resolution spectrum of V $2 p$; (f) high-resolution spectrum of $\mathrm{O} 1 \mathrm{~s}$.

\subsection{Formation Mechanism of the Ca-P-V Composite Coating}

According to the above results, a formation mechanism of the composite $\mathrm{Ca}-\mathrm{P}-\mathrm{V}$ coating is schematically depicted in Figure 4. It is known that the valence state of $\mathrm{V}$ in the solution depends on the solution $\mathrm{pH}$ value and the concentration of $\mathrm{V}$. In this study, the concentration of $\mathrm{V}$ is $0.08 \mathrm{M}$ and the $\mathrm{pH}$ of the conversion solution is 3, the colour of the conversion solution is red (Figure S2), indicating that vanadium exists in a form of $\mathrm{VO}^{2+}[25,32]$. Low corrosion potential of $\alpha$-Mg promoted the formation of $\mathrm{Mg}^{2+}$ (Equation (1)); hydrogen was given off from the $\beta-\mathrm{Al}_{17} \mathrm{Mg}_{12}$ (Equation (2)), which has a higher potential (Figure 4a).

$$
\begin{aligned}
& \mathrm{Mg} \rightarrow \mathrm{Mg}^{2+}+2 \mathrm{e}^{-} \\
& 2 \mathrm{H}^{+}+2 \mathrm{e}^{-} \rightarrow \mathrm{H}_{2} \uparrow
\end{aligned}
$$


The above reactions raise the $\mathrm{pH}$ of the solution adjacent to the metal surface (from 3 to 7-8) $[1,2,33,34]$, which makes $\mathrm{H}_{2} \mathrm{PO}_{4}{ }^{-}$being transferred into $\mathrm{HPO}_{4}{ }^{2-}$ and $\mathrm{PO}_{4}{ }^{3-}$ according to the following reactions [33]:

$$
\begin{gathered}
\mathrm{H}_{2} \mathrm{PO}_{4}{ }^{-}+\mathrm{OH}^{-} \rightarrow \mathrm{HPO}_{4}{ }^{2-}+\mathrm{H}_{2} \mathrm{O} \\
\mathrm{HPO}_{4}{ }^{2-}+\mathrm{OH}^{-} \rightarrow \mathrm{PO}_{4}{ }^{3-}+\mathrm{H}_{2} \mathrm{O}
\end{gathered}
$$

As a result, the generated $\mathrm{HPO}_{4}{ }^{2-}$ and $\mathrm{PO}_{4}{ }^{3-}$ may react with the $\mathrm{Ca}^{2+}$ and $\mathrm{Mg}^{2+}$ in the solution to form insoluble $\mathrm{CaHPO}_{4} \cdot 2 \mathrm{H}_{2} \mathrm{O}, \mathrm{Ca}_{3}\left(\mathrm{PO}_{4}\right)_{2}$ and $\mathrm{Mg}_{3}\left(\mathrm{PO}_{4}\right)_{2}$ precipitates on the substrate surface according to the following reactions $[35,36]$ :

$$
\begin{gathered}
\mathrm{Ca}^{2+}+\mathrm{HPO}_{4}{ }^{2-}+2 \mathrm{H}_{2} \mathrm{O} \rightarrow \mathrm{CaHPO}_{4} \cdot 2 \mathrm{H}_{2} \mathrm{O} \\
3 \mathrm{Ca}^{2+}+2 \mathrm{PO}_{4}{ }^{3-} \rightarrow \mathrm{Ca}_{3}\left(\mathrm{PO}_{4}\right)_{2} \\
3 \mathrm{Mg}^{2+}+2 \mathrm{PO}_{4}{ }^{3-} \rightarrow \mathrm{Mg}_{3}\left(\mathrm{PO}_{4}\right)_{2}
\end{gathered}
$$

$\mathrm{MgHPO}_{4}$ is not involved in the conversion coating, because it is slightly soluble in aqueous solution [27]. The values of the thermodynamic function $\mathrm{H}_{0}$ for $\mathrm{Mg}_{3}\left(\mathrm{PO}_{4}\right)_{2}$ and $\mathrm{Mg}(\mathrm{OH})_{2}$ are -3780.66 and $-924.16 \mathrm{~kJ} / \mathrm{mol}$, respectively $[16,27,35]$. Thus, $\mathrm{Mg}^{2+}$ preferentially reacts with $\mathrm{PO}_{4}{ }^{3-}$ to form $\mathrm{Mg}_{3}\left(\mathrm{PO}_{4}\right)_{2}$ rather than $\mathrm{Mg}(\mathrm{OH})_{2}$. The composition of the products of the reactions (5)-(7) can be proved by the XPS results. Meanwhile, the increase of the solution $\mathrm{pH}$ also triggers the formation of $\mathrm{VO}(\mathrm{OH})_{3}$ through hydrolysis of $\mathrm{VO}^{2+}[26,32,37]$ :

$$
\mathrm{VO}_{2}{ }^{+}+2 \mathrm{H}_{2} \mathrm{O} \rightarrow \mathrm{VO}(\mathrm{OH})_{3}+\mathrm{H}^{+}
$$

Figure S2 shows that after chemical conversion treatment the colour of the solution is still red, indicating the form of $\mathrm{V}(\mathrm{V})$. Therefore, the final structure of the $\mathrm{Ca}-\mathrm{P}-\mathrm{V}$ coating is a grid-like film composed of $\mathrm{CaHPO}_{4} \cdot 2 \mathrm{H}_{2} \mathrm{O}, \mathrm{Ca}_{3}\left(\mathrm{PO}_{4}\right)_{2}$ and $\mathrm{Mg}_{3}\left(\mathrm{PO}_{4}\right)_{2}$ with some hydroxides of $\mathrm{V}(\mathrm{V})$ dispersed into the film (Figure 4c).
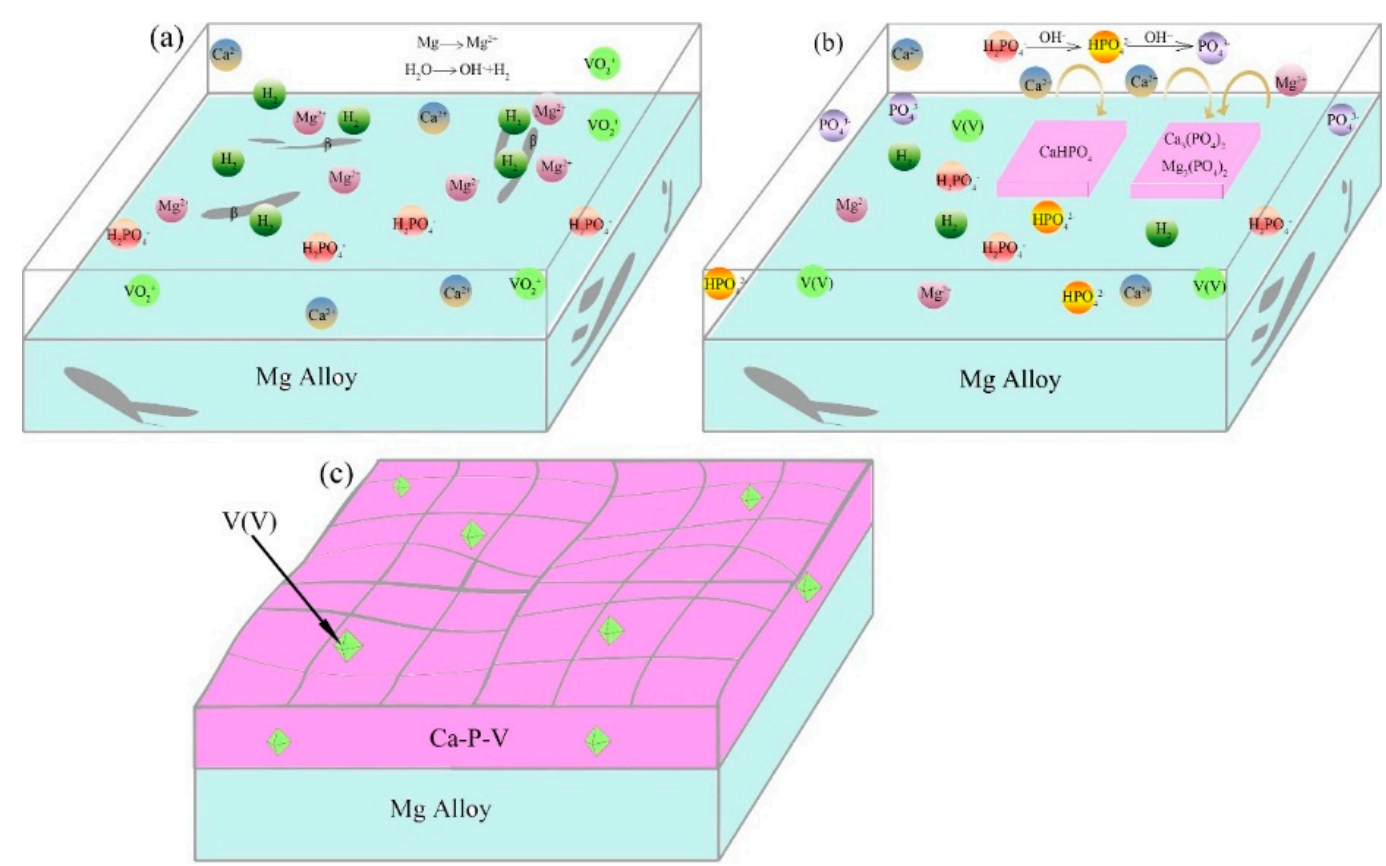

Figure 4. Schematic illustration of the formation mechanism of the Ca-P-V composite coating on AZ91D substrate: (a) dissolution of magnesium and evolution of hydrogen; (b) nuclei formation of $\mathrm{CaHPO}_{4} \cdot 2 \mathrm{H}_{2} \mathrm{O}, \mathrm{Ca}_{3}\left(\mathrm{PO}_{4}\right)_{2}$, and $\mathrm{Mg}_{3}\left(\mathrm{PO}_{4}\right)_{2} ;(\mathbf{c})$ conversion layer formed over the entire surface. 


\subsection{Anticorrosion Property of the $C a-P-V$ Coated Samples}

To study the anticorrosion property of the samples, both the potentiodynamic polarization measurements and EIS analysis were carried out on different specimens in $3.5 \mathrm{wt} \% \mathrm{NaCl}$ solution. Furthermore, to study the self-healing behaviour of the specimens, the $\mathrm{Ca}-\mathrm{P}-\mathrm{V}$ composite coatings were soaked in $3.5 \mathrm{wt} \% \mathrm{NaCl}$ solution for different times before electrochemical tests. The $\mathrm{Ca}-\mathrm{P}-\mathrm{V}$ coated sample $(0 \mathrm{~d})$ indicates the sample is not soaked in solution before tests.

Figure 5 shows the polarization curves of the uncoated and $\mathrm{Ca}-\mathrm{P}-\mathrm{V}$ coated samples after being immersed for different times $(0,1,2$, and $3 \mathrm{~d})$. The corrosion parameters of the samples derived from Figure 5 are shown in Table 2, where $E_{\text {corr }}$ and $I_{\text {corr }}$ are corrosion potential and corrosion current density, respectively. Comparing with the uncoated AZ91D substrate, the Ca-P-V coated sample $(0 \mathrm{~d})$ has a lower $E_{\text {corr }}$. But the $E_{\text {corr }}$ values of the composite coating increased gradually with increasing immersion time, suggesting that the initial pitting corrosion can be suppressed by further immersion in solution. Compared to the uncoated AZ91D, the $I_{\text {corr }}$ of the coated samples is dropped by two orders of magnitude, which indicates the anticorrosion ability is greatly improved due to the conversion coating. Notably, the $I_{\text {corr }}$ of the coated samples decreases from $1.39 \times 10^{-6}$ to $3.84 \times 10^{-7} \mathrm{~A} / \mathrm{cm}^{2}$ with the extended immersion time from $1-3 \mathrm{~d}$, which demonstrates a remarkably restrained corrosion process. It is obvious that the $\mathrm{Ca}-\mathrm{P}-\mathrm{V}$ coated sample after being immersed for $3 \mathrm{~d}$ exhibits the best corrosion resistance and a self-healing behaviour.

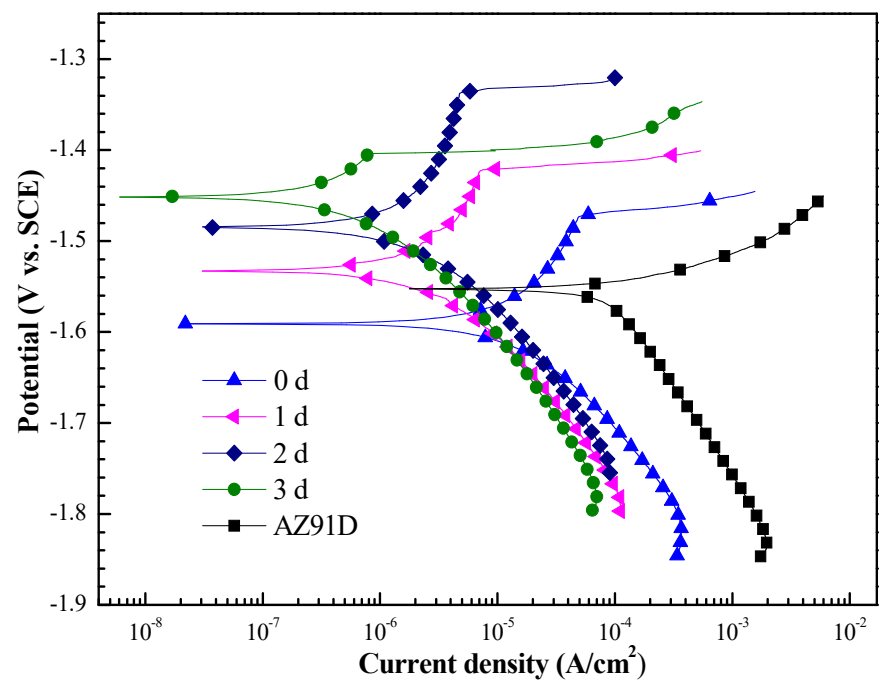

Figure 5. The polarization curves of the uncoated AZ91D substrate and the Ca-P-V coated samples in $3.5 \mathrm{wt} \% \mathrm{NaCl}$ solution after immersion for different days before tests.

Table 2. Corrosion parameters of the AZ91D substrate and various conversion coatings derived from Figure 5. $\beta_{a}$ and $\beta_{c}$ are the cathodic and anodic Tafel slopes.

\begin{tabular}{ccccc}
\hline Samples & $E_{\text {corr }}(\mathrm{V} / \mathrm{SCE})$ & $\beta_{a}(\mathrm{mV} / \mathrm{dec})$ & $\beta_{c}(\mathrm{mV} / \mathrm{dec})$ & $I_{\text {corr }}\left(\mathrm{A} / \mathrm{cm}^{2}\right)$ \\
\hline $0 \mathrm{~d}$ & $-1.59 \pm 0.02$ & 84.3 & -71.7 & $9.1 \times 10^{-6}$ \\
$1 \mathrm{~d}$ & $-1.53 \pm 0.03$ & 88.1 & -69.1 & $1.39 \times 10^{-6}$ \\
2 d & $-1.48 \pm 0.01$ & 98.1 & -64.0 & $1.04 \times 10^{-6}$ \\
3 d & $-1.45 \pm 0.02$ & 95.7 & -65.1 & $3.84 \times 10^{-7}$ \\
AZ91D & $-1.55 \pm 0.01$ & 42.3 & -462.8 & $1.56 \times 10^{-4}$ \\
\hline
\end{tabular}

Figure S3 shows the OCP data of the uncoated AZ91D as well as the Ca-P-V coated samples $(0 \mathrm{~d})$ in $3.5 \mathrm{wt} \% \mathrm{NaCl}$ solution. For the uncoated AZ91D substrate, the OCP decreases to a steady value of $-1.585 \mathrm{~V}$ (vs. SCE) with less fluctuation in about $15 \mathrm{~min}$. The initial OCP of the coated sample $(0 \mathrm{~d})$ is relatively negative, which may due to some defects such as micro-cracks (as shown in Figure 2c) in 
the coating that results in the substrate to be exposed to electrolyte. However, the OCP of the coated sample $(0 \mathrm{~d})$ after $10 \mathrm{~min}$ increases gradually with time and finally reaches a relative constant value of about $-1.684 \mathrm{~V}$ (vs. SCE) after 40 min of soaking. The Nyquist plots for uncoated AZ91D substrate and Ca-P-V coated samples after being soaked in $3.5 \mathrm{wt} \% \mathrm{NaCl}$ solution for $0,1,2$ and $3 \mathrm{~d}$ at OCP are shown in Figure S4 and Figure 6, respectively. The plot of the uncoated AZ91D substrate consists of two loops. The inductive loop in the low frequency may result from the relaxation of the absorbed species, indicating the occurrence of pitting corrosion [38,39]. Moreover, the diameter of the capacitive loop has a trend of first increases and decreases with the extension of soaking time (Figure S4). This is because the protective effect of corrosion products on the substrate is weak and will gradually lose its protective effect with the increase of immersion time. The $\mathrm{Ca}-\mathrm{P}-\mathrm{V}$ composite coating after immersion for different days show capacitive loops at high frequencies with weak inductive loops at the low frequencies. The corresponding equivalent circuit models used to fit the EIS data of the uncoated AZ91D and the $\mathrm{Ca}-\mathrm{P}-\mathrm{V}$ coated sample ( $3 \mathrm{~d}$ ) were inserted in Figure 6. The capacitive loops at high frequencies of the coated samples can be referred to the good barrier properties of the Ca-P-V composite coating [40], and the weakening of the inductive loops also indicates the better performance of the coating with improved pitting corrosion resistance. Moreover, the capacitive loop diameter increases gradually with the increase of immersion time, which suggests an improved corrosion resistance. These confirm that the anticorrosion ability of the composite coating does not reduce but is increased with the extension of immersion time.

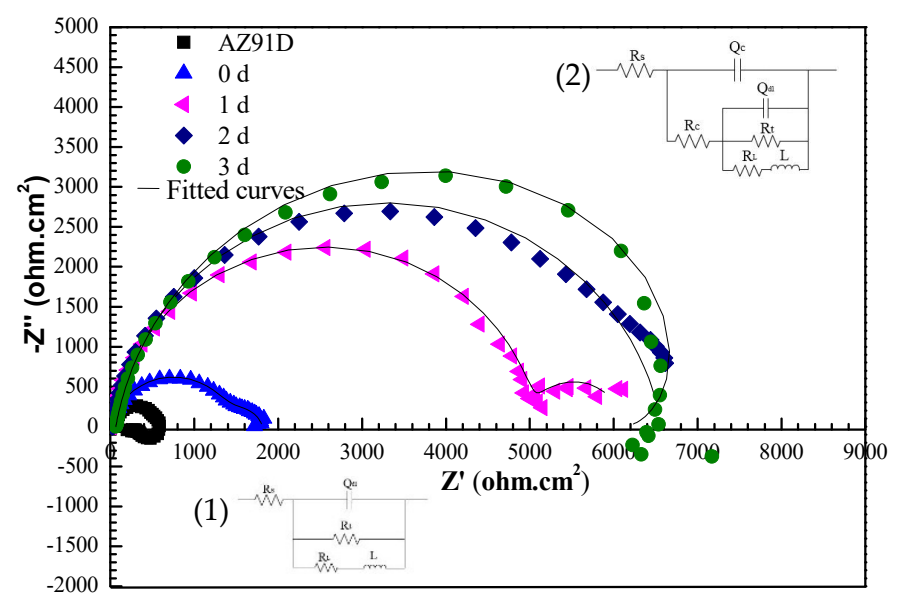

(a)

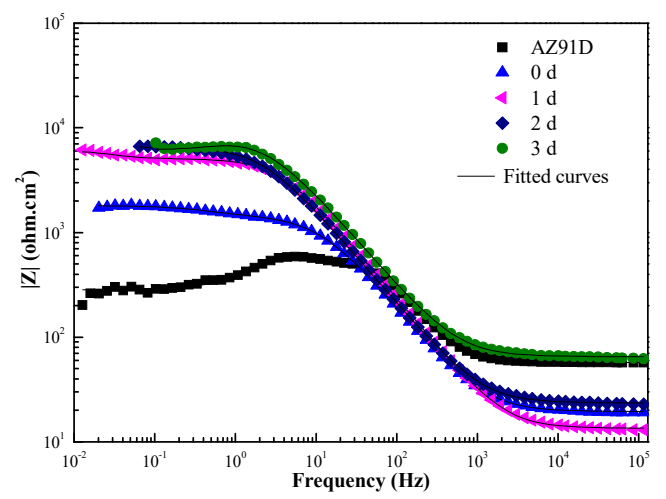

(b)

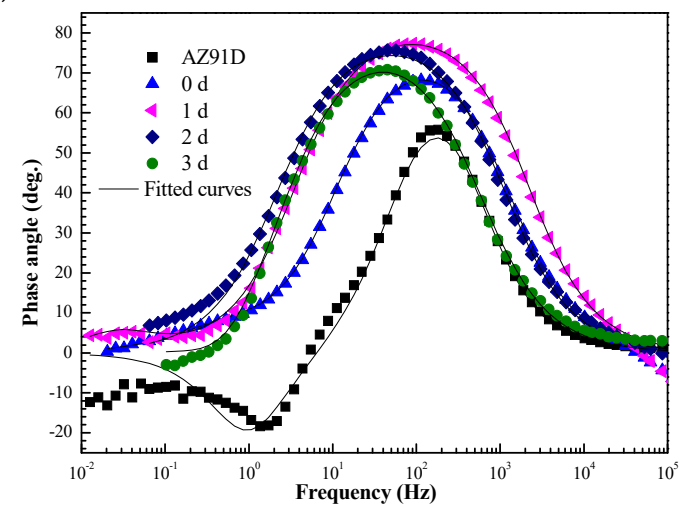

(c)

Figure 6. EIS plots for uncoated AZ91D substrate and Ca-P-V coated samples at their open circuit potential after immersion for different days in $3.5 \mathrm{wt} \% \mathrm{NaCl}$ solution. (a) Nyquist plots; (b) Bode plots of $|\mathrm{Z}|$ vs. frequency; (c) Bode plots of Phase angle vs. frequency. (Symbols are experimental data and solid lines are fitting data. The subfigures in (a) are the equivalent circuit models of (1) the uncoated AZ91D substrate and (2) the Ca-P-V coated samples after immersion for $3 \mathrm{~d}$.) 


\subsection{Self-Healing Behaviour of the Scratched $C a-P-V$ Coated Specimens}

SEM morphologies of the scratched Ca-P-V coated samples after being immersed in $3.5 \mathrm{wt} \%$ $\mathrm{NaCl}$ solution are shown in Figure 7. Figure 7a shows that the new scratch is smooth and the edge of the scratch is sharp. After $1 \mathrm{~d}$ immersion, some newly formed precipitates appear on the bottom of the scratch (Figure $7 \mathrm{~b}$ ). With the prolongation of soaking time, the precipitates increase and gradually fill the scratch, and the edge of the scratch becomes indistinct. After being immersed for $3 \mathrm{~d}$ (Figure $7 \mathrm{~d}$ ), the scratch becomes relatively flat and is fully and closely covered by spherical particles. Furthermore, Figure 7e shows that the spherical particles have a flower-like morphology with many nanoplates interspersed with each other. Except for the flower-like precipitates, there are some other precipitates covered on them as indicated by the square in Figure 7e. The flower-like morphology of the newly formed spherical particles is similar to that reported about the self-healing behaviour of single $\mathrm{V}$ coating by other researchers [22-24]. Consequently, the scratch was covered by more and more spherical particles and was sealed in this way to prevent further contact with the corrosion solution (Figure S5). These results are consistent with the EIS result, proving the self-healing property of the coating.

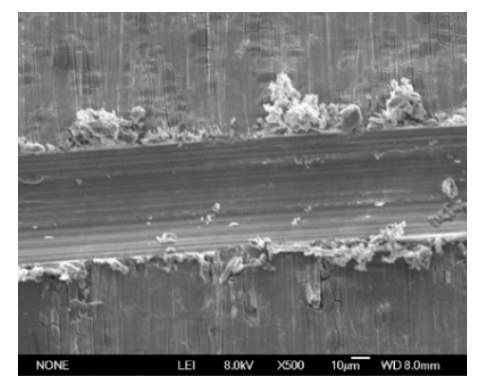

(a)

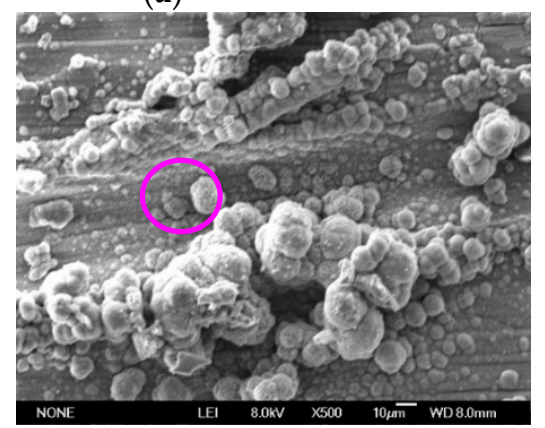

(d)

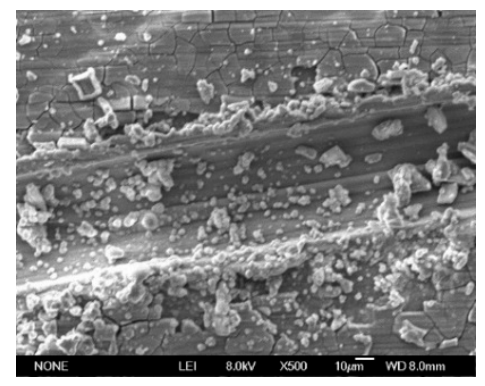

(b)

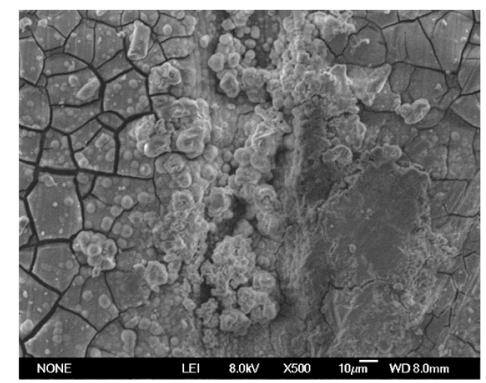

(c)

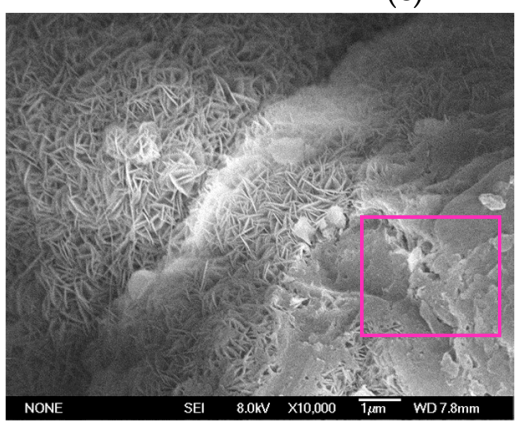

(e)

Figure 7. SEM morphologies of the scratched Ca-P-V coatings in $3.5 \mathrm{wt} \% \mathrm{NaCl}$ solution for different days: (a) $0 \mathrm{~d}$; (b) $1 \mathrm{~d}$; (c) $2 \mathrm{~d}$; (d) $3 \mathrm{~d}$; (e) $3 \mathrm{~d}$.

To study the self-healing mechanism of the Ca-P-V composite coating, the EDS analysis at the scratch of the Ca-P-V coated sample before and after immersion was conducted as shown in Figure 8a,b. As a comparison, the SEM-EDS analysis of the uncoated AZ91D with a scratch after immersion in $3.5 \mathrm{wt} \% \mathrm{NaCl}$ solution for $2 \mathrm{~d}$ was also conducted (Figure 8c). The scratch of the Ca-P-V coated sample before immersion mainly consists of $\mathrm{Mg}, \mathrm{Al}$ and $\mathrm{Zn}$ (Figure 8a), which is the same composition as the AZ91D substrate. After being corroded for $2 \mathrm{~d}$, the newly formed compound contains $\mathrm{Ca}, \mathrm{P}, \mathrm{O}$ and $\mathrm{V}$ elements, except for the $\mathrm{Mg}$ and $\mathrm{Al}$ elements mainly from the substrate (Figure $8 \mathrm{~b}$ ), implying the formation of calcium phosphate and/or hydrogen phosphate, magnesium phosphate and vanadium oxides and/or hydroxides. Figure $8 \mathrm{c}$ shows that some loose corrosion products are gathered around the scratch of the uncoated sample and the corresponding EDS analysis indicates that the corrosion products are composed of $\mathrm{Mg}$ and $\mathrm{O}$, which is different from the products formed on the scratched $\mathrm{Ca}-\mathrm{P}-\mathrm{V}$ coated sample as shown in Figure $8 \mathrm{~b}$. Therefore, it can be concluded that the products appeared on the scratched $\mathrm{Ca}-\mathrm{P}-\mathrm{V}$ coating after immersion are newly formed compounds rather than 
corrosion products, suggesting that $\mathrm{Ca}, \mathrm{P}$ as well as $\mathrm{V}$ elements can migrate from the surrounding layer to the scratched zone and form some new compounds. The self-healing ability of the Ca-P-V composite coating is beneficial for AZ91D alloy because it can prevent further corrosion through repairing scratches or cracks.

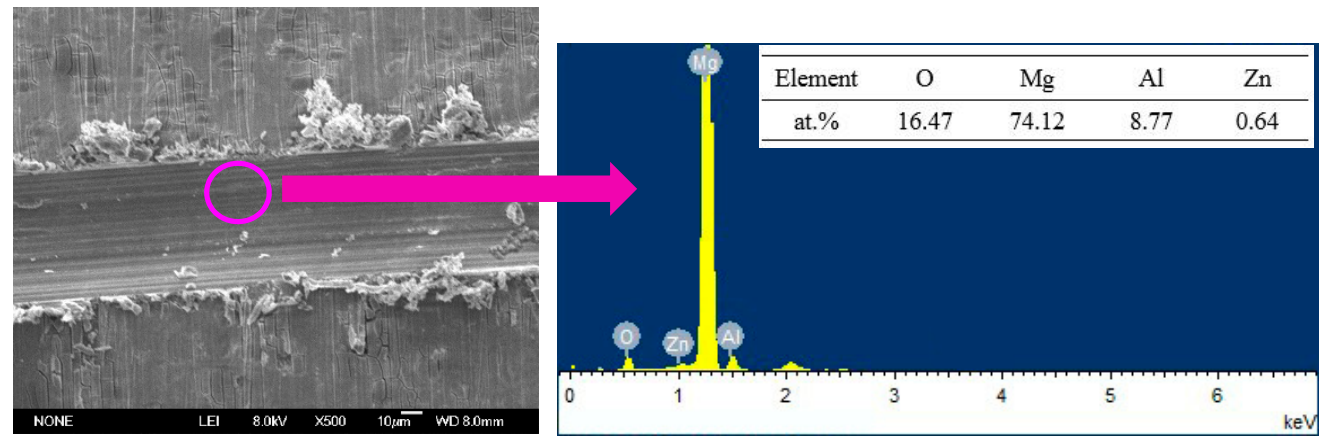

(a)
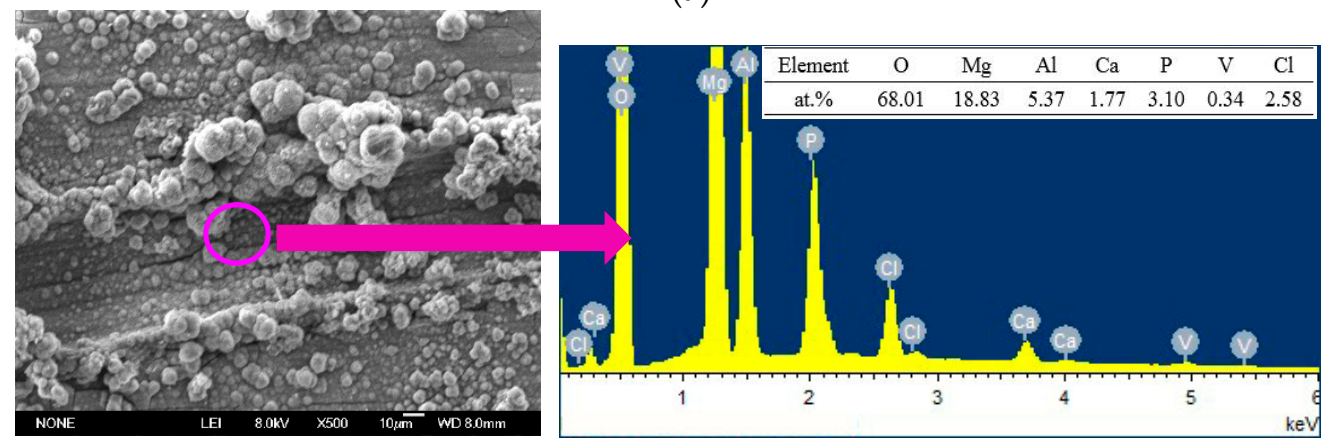

(b)
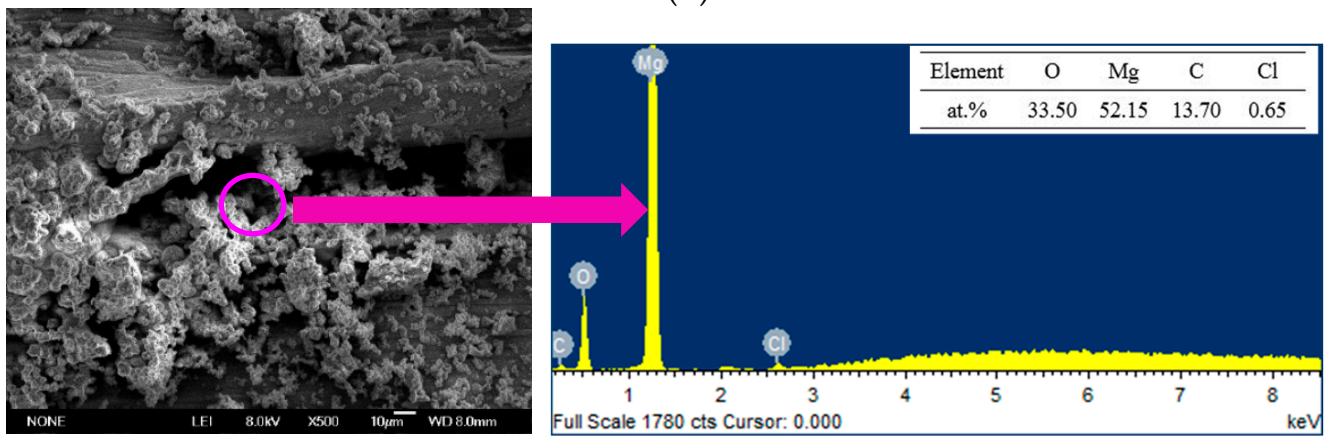

(c)

Figure 8. SEM-EDS results of the scratched samples: (a) Ca-P-V coating before immersion; (b) $\mathrm{Ca}-\mathrm{P}-\mathrm{V}$ coating after immersion for $2 \mathrm{~d}$; (c) the uncoated AZ91D after immersion for $2 \mathrm{~d}$ in $3.5 \mathrm{wt} \%$ $\mathrm{NaCl}$ solution.

\section{Conclusions}

In this study, a new self-healing $\mathrm{Ca}-\mathrm{P}-\mathrm{V}$ conversion coating on AZ91D alloy was designed as a chromate replacement. The $\mathrm{Ca}-\mathrm{P}-\mathrm{V}$ composite coating exhibits a grid-like structure and mainly consists of $\mathrm{CaHPO}_{4}, \mathrm{Ca}_{3}\left(\mathrm{PO}_{4}\right)_{2}$ and $\mathrm{Mg}_{3}\left(\mathrm{PO}_{4}\right)_{2}$ with some hydroxides of $\mathrm{V}(\mathrm{V})$ dispersed into the coating. The electrochemical tests demonstrate that the anticorrosion property of the $\mathrm{Ca}-\mathrm{P}-\mathrm{V}$ coated substrate is enhanced obviously. Moreover, the Ca-P-V composite coating exhibits good self-healing ability according to the scratch immersion and electrochemical tests. Both $\mathrm{Ca}, \mathrm{P}$, and $\mathrm{V}$ play important roles in the self-healing process of the coating in this study. The composite $\mathrm{Ca}-\mathrm{P}-\mathrm{V}$ coating with enhanced anticorrosion performance and self-healing property may have great potential for use as a replacement for chromate conversion coating. 
Supplementary Materials: The following are available online at http://www.mdpi.com/2079-6412/9/6/379/s1, Figure S1: SEM images and EDS analysis of (a) pure V coating and (b) Ca-P coating, Figure S2: photos of the different solutions: (a) the $\mathrm{NaVO}_{3}$ solution; (b) the conversion solution after adjusting $\mathrm{pH}$ to 3.0; (c) the conversion solution after removing the AZ91D samples, Figure S3: open circuit potential curves of the uncoated AZ91D substrate and the substrate coated with $\mathrm{Ca}-\mathrm{P}-\mathrm{V}$ composite coating in $3.5 \mathrm{wt} \% \mathrm{NaCl}$ solution as a function of time. The Ca-P-V coated sample $(0 \mathrm{~d})$ indicates the sample is not immersed in $3.5 \mathrm{wt} \% \mathrm{NaCl}$ solution before OCP test, Figure S4: Nyquist plots for uncoated AZ91D substrate after immersion for different days in $3.5 \mathrm{wt} \% \mathrm{NaCl}$ solution, Figure S5: SEM images of the Ca-P-V coating after immersion in $3.5 \mathrm{wt} \% \mathrm{NaCl}$ solution for (a) $3 \mathrm{~d}$ and (b) $5 \mathrm{~d}$.

Author Contributions: Conceptualization, R.S.; Investigation, T.L. and S.Y.; Writing-Original Draft Preparation, T.L.; Writing-Review and Editing, R.S. and S.Y.

Funding: This research was funded by the National Natural Science Foundation of China (Project No. 51602169).

Acknowledgments: We thank LetPub (www.letpub.com) for its linguistic assistance during the preparation of this manuscript.

Conflicts of Interest: The authors declare no conflict of interest.

\section{References}

1. Jayaraj, J.; Raj, S.A.; Srinivasan, A.; Ananthakumar, S.; Pillai, U.T.S.; Dhaipule, N.G.K.; Mudali, U.K. Composite magnesium phosphate coatings for improved corrosion resistance of magnesium AZ31 alloy. Corros. Sci. 2016, 113, 104-115. [CrossRef]

2. Chen, X.B.; Birbilis, N.; Abbott, T.B. A simple route towards a hydroxyapatite- $\mathrm{Mg}(\mathrm{OH})_{2}$ conversion coating for magnesium. Corros. Sci. 2011, 53, 2263-2268. [CrossRef]

3. Zhang, Y.; Tang, S.; Hu, J.; Lin, T. Formation mechanism and corrosion resistance of the hydrophobic coating on anodized magnesium. Corros. Sci. 2016, 111, 334-343. [CrossRef]

4. Gray, J.; Luan, B. Protective coatings on magnesium and its alloys-A critical review. J. Alloy Compd. 2002, 336, 88-113. [CrossRef]

5. Wang, J.L.; Ke, C.; Pohl, K.; Birbilis, N.; Chen, X.B. The unexpected role of benzotriazole in mitigating magnesium alloy corrosion: A nucleating agent for crystalline nanostructured magnesium hydroxide film. J. Electrochem. Soc. 2015, 162, C403-C411. [CrossRef]

6. Blawert, C.; Dietzel, W.; Ghali, E.; Song, G. Anodizing treatments for magnesium alloys and their effect on corrosion resistance in various environments. Adv. Eng. Mater. 2006, 8, 511-533. [CrossRef]

7. Khan, S.A.; Miyashita, Y.; Mutoh, Y. Corrosion fatigue behavior of AM60 magnesium alloy with anodizing layer and chemical-conversion-coating layer. Mater. Corros. 2015, 66, 940-948. [CrossRef]

8. Wang, S.H.; Guo, X.W.; Sun, C.; Gong, J.; Peng, L.M.; Ding, W.J. Electrodeposition of Cu coating with high corrosion resistance on $\mathrm{Mg}-3.0 \mathrm{Nd}-0.2 \mathrm{Zn}-0.4 \mathrm{Zr}$ magnesium alloy. Trans. Nonferrous Met. Soc. China 2014, 24, 3810-3817. [CrossRef]

9. Liu, Y.; Yin, X.; Zhang, J.; Yu, S.; Han, Z.; Ren, L. A electro-deposition process for fabrication of biomimetic super-hydrophobic surface and its corrosion resistance on magnesium alloy. Electrochim. Acta 2014, 125, 395-403. [CrossRef]

10. Lu, X.; Blawert, C.; Kainer, K.U.; Zheludkevich, M.L. Investigation of the formation mechanisms of plasma electrolytic oxidation coatings on Mg alloy AM50 using particles. Electrochim. Acta 2016, 196, 680-691. [CrossRef]

11. Klein, M.; Lu, X.; Blawert, C.; Kainer, K.U.; Zheludkevich, M.L.; Walther, F. Influence of plasma electrolytic oxidation coatings on fatigue performance of AZ31 Mg alloy. Mater. Corros. 2017, 68, 50-57. [CrossRef]

12. Surmeneva, M.A.; Ivanova, A.A.; Tian, Q.M.; Pittman, R.; Jiang, W.S.; Lin, J.J.; Liu, H.H.; Surmenev, R.A. Bone marrow derived mesenchymal stem cell response to the RF magnetron suppter deposited hydroxyapatite coating on AZ91 magnesium alloy. Mater. Chem. Phys. 2019, 221, 89-98. [CrossRef]

13. Mukhametkaliyev, T.M.; Surmeneva, M.A.; Vladescu, A.; Cotrut, C.M.; Braic, M.; Dinu, M.; Vranceanu, M.D.; Pana, I.; Mueller, M.; Surmenev, R.A. A biodegradable AZ91 magnesium alloy coated with a thin nanostructured hydroxyapatite for improving the corrosion resistance. Mat. Sci. Eng. C 2017, 75, 95-103. [CrossRef] [PubMed]

14. Chen, L.X.; Liu, Y.; Liu, Z.Y.; Zhao, X.Y.; Li, W. Improving corrosion resistance of AZ91D magnesium alloy by laser surface melting and micro-arc oxidation. Mater. Corros. 2015, 66, 963-970. [CrossRef] 
15. Yang, N.; Li, Q.; Chen, F.; Cai, P.; Tan, C.; Xi, Z. A solving-reprecipitation theory for self-healing functionality of stannate coating with a high environmental stability. Electrochim. Acta 2015, 174, 1192-1201. [CrossRef]

16. Pommiers, S.; Frayret, J.; Castetbon, A.; Potin-Gautier, M. Alternative conversion coatings to chromate for the protection of magnesium alloys. Corros. Sci. 2014, 84, 135-146. [CrossRef]

17. Qi, J.; Gao, L.; Li, Y.; Wang, Z.; Thompson, G.E.; Skeldon, P. An optimized trivalent chromium conversion coating process for AA2024-T351 alloy. J. Electrochem. Soc. 2017, 164, C390-C395. [CrossRef]

18. Van Phuong, N.; Lee, K.; Chang, D.; Kim, M.; Lee, S.; Moon, S. Zinc phosphate conversion coatings on magnesium alloys: a review. Met. Mater. Int. 2013, 19, 273-281. [CrossRef]

19. Sun, R.X.; Wang, P.F.; Zhao, D.D.; Sun, Z.Z.; Li, C.Q.; Chen, K.Z. An environment-friendly calcium phosphate conversion coating on AZ91D alloy and its corrosion resistance. Mater. Corros. 2015, 66, 383-386. [CrossRef]

20. Zeng, R.C.; Zhang, F.; Lan, Z.D.; Cui, H.Z.; Han, E.H. Corrosion resistance of calcium-modified zinc phosphate conversion coatings on magnesium-aluminium alloys. Corros. Sci. 2014, 88, 452-459. [CrossRef]

21. Chen, X.B.; Zhou, X.; Abbott, T.B.; Easton, M.A.; Birbilis, N. Double-layered manganese phosphate conversion coating on magnesium alloy AZ91D: Insights into coating formation, growth and corrosion resistance. Surf. Coat. Technol. 2013, 217, 147-155. [CrossRef]

22. Hamdy, A.S.; Doench, I.; Möhwald, H. Assessment of a one-step intelligent self-healing vanadia protective coatings for magnesium alloys in corrosive media. Electrochim. Acta 2011, 56, 2493-2502. [CrossRef]

23. Hamdy, A.S.; Doench, I.; Möhwald, H. Vanadia-based coatings of self-repairing functionality for advanced magnesium Elektron ZE41 Mg-Zn-rare earth alloy. Surf. Coat. Technol. 2012, 206, 3686-3692. [CrossRef]

24. Li, K.; Liu, J.; Lei, T.; Xiao, T. Optimization of process factors for self-healing vanadium-based conversion coating on AZ31 magnesium alloy. Appl. Sur. Sci. 2015, 353, 811-819. [CrossRef]

25. Jiang, X.; Guo, R.; Jiang, S. Microstructure and corrosion resistance of Ce-V conversion coating on AZ31 magnesium alloy. Appl. Sur. Sci. 2015, 341, 166-174. [CrossRef]

26. Zhong, X.; Wu, X.; Jia, Y.; Liu, Y. Self-repairing vanadium-zirconium composite conversion coating for aluminum alloys. Appl. Surf. Sci. 2013, 280, 489-493. [CrossRef]

27. Song, Y.; Shan, D.; Chen, R.; Zhang, F.; Han, E.H. A novel phosphate conversion film on Mg-8.8Li alloy. Surf. Coat. Technol. 2009, 203, 1107-1113. [CrossRef]

28. Zeng, R.C.; Lan, Z.D.; Kong, L.H.; Huang, Y.D.; Cui, H.Z. Characterization of calcium-modified zinc phosphate conversion coatings and their influences on corrosion resistance of AZ31 alloy. Surf. Coat. Technol. 2011, 205, 3347-3355. [CrossRef]

29. Silversmit, G.; Depla, D.; Poelman, H.; Marin, G.B.; De Gryse, R. Determination of the V $2 p$ XPS binding energies for different vanadium oxidation states $\left(\mathrm{V}^{5+}\right.$ to $\left.\mathrm{V}^{0+}\right)$. J. Electron Spectrosc. Relat. Phenom. 2004, 135, 167-175. [CrossRef]

30. Wu, Q.H.; Thissen, A.; Jaegermann, W.; Liu, M. Photoelectron spectroscopy study of oxygen vacancy on vanadium oxides surface. Appl. Sur. Sci. 2004, 236, 473-478. [CrossRef]

31. Moulder, J.F.; Chastain, J.; King, R.C. Handbook of X-Ray Photoelectron Spectroscopy: A Reference Book of Standard Spectra for Identification and Interpretation of XPS Data; Physical Electronics: Eden Prairie, MN, USA, 1995.

32. Zou, Z.L.; Li, N.; Li, D.Y.; Liu, H.P.; Mu, S.L. A vanadium-based conversion coating as chromate replacement for electrogalvanized steel substrates. J. Alloy Compd. 2011, 509, 503-507. [CrossRef]

33. Chu, Y.R.; Lin, C.S. Citrate gel conversion coating on AZ31 magnesium alloys. Corros. Sci. 2014, 87, $288-296$. [CrossRef]

34. Chen, X.B.; Birbilis, N.; Abbott, T.B. Effect of $\left[\mathrm{Ca}^{2+}\right]$ and $\left[\mathrm{PO}_{4}{ }^{3-}\right]$ levels on the formation of calcium phosphate conversion coatings on die-cast magnesium alloy AZ91D. Corros. Sci. 2012, 55, 226-232. [CrossRef]

35. Song, Y.; Shan, D.; Chen, R.; Zhang, F.; Han, E.H. Formation mechanism of phosphate conversion film on Mg-8.8Li alloy. Corros. Sci. 2009, 51, 62-69. [CrossRef]

36. Su, Y.; Niu, L.; Lu, Y.; Lian, J.; Li, G. Preparation and corrosion behavior of calcium phosphate and hydroxyapatite conversion coatings on AM60 magnesium alloy. J. Electrochem. Soc. 2013, 160, C536-C541. [CrossRef]

37. Livage, J. Sol-gel chemistry and electrochemical properties of vanadium oxide gels. Solid State Ionics 1996, 86, 935-942. [CrossRef]

38. Li, J.R.; Jiang, Q.T.; Sun, H.Y.; Li, Y.T. Effect of heat treatment on corrosion behavior of AZ63 alloy in 3.5 wt. \% sodium chloride solution. Corros. Sci. 2016, 111, 288-301. [CrossRef] 
39. Sun, M.; Yerokhin, A.; Bychkova, M.Y.; Shtansky, D.V.; Levashov, E.A.; Matthews, A. Self-healing plasma electrolytic oxidation coating doped with benzotrizaole loaded halloysite nanotubes on AM50 magnesium alloy. Corros. Sci. 2016, 111, 753-769. [CrossRef]

40. Gnedenkov, S.V.; Sinebryukhov, S.L.; Mashtalyar, D.V.; Nadaraia, K.V.; Gnedenkov, A.S.; Bouznik, V.M. Composite fluoropolymer coatings on the MA8 magnesium alloy surface. Corros. Sci. 2016, 111, 175-185. [CrossRef]

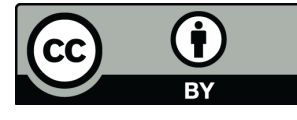

(C) 2019 by the authors. Licensee MDPI, Basel, Switzerland. This article is an open access article distributed under the terms and conditions of the Creative Commons Attribution (CC BY) license (http://creativecommons.org/licenses/by/4.0/). 